\title{
Economic analysis of trout feed production in Jammu and Kashmir, India
}

\author{
Stanzin Gawa*, Nalini Ranjan Kumar, Swadesh Prakash, Vinod Kumar Yadav, Vinay \\ Maruti Hatte and Navghan Mahida
}

ICAR-Central Institute of Fisheries Education, Mumbai - 400061 (Maharashtra), INDIA

*Corresponding author. E-mail: gawa107@gmail.com

Received: April 18, 2017; Revised received: June 8, 2017; Accepted: October 30, 2017

\begin{abstract}
The Present study is an attempt to understand the economics of trout feed production in the state of Jammu and Kashmir. Trout feed production is capital intensive business which requires high initial capital investment. The results revealed that major fixed investment required in trout feed production was feed mill itself which accounted about 71.44 percent of the total investment. The cost and return analysis showed that the variable cost accounts 59.16 percent whereas fixed cost accounted 40.84 percent of the total cost respectively. Among the variable cost raw material was found out to be single most important factor which accounted about 56.37 percent of the total cost which was about 95.28 percent of the total variable cost. The average cost of production of trout feed was Rs.84.33/kg which ranged from Rs.78.45/kg in Kokarnag trout feed mill to Rs.90.2/kg in Manasbal trout feed mill but government has fixed selling price at Rs.73/Kg for the feed to maintain reasonable price level for private trout farmers. The availability and high price of raw material were found to be major constraints faced by feed producers. Economics analysis revealed that both the feed mills are operating at suboptimal level and there is need to utilize the feed mill to its full potential and export the surplus production to neighbouring state of Himachal Pradesh and other Himalayan states like Sikkim and Arunachal which will help the state fisheries department to generate extra income which can be used in other developmental activities.
\end{abstract}

Keywords: Cost and return, Feed production, Jammu and Kashmir, Trout

\section{INTRODUCTION}

It is a well-known fact that the people in the hilly regions has limited livelihood options and frequently suffer from lack of nutritional and protein rich food. These regions have also been facing rising unemployment and also lack of employment opportunities. Recently in year 2009-2010 the Jammu and Kashmir fisheries department has identified trout culture as source of employment for youth of the state and started privatization of trout culture under RKVY (centrally sponsored scheme) under which they provide 80 percent subsidy and rest 20 percent is to be borne by the beneficiary (Gawa et al., 2016). Jammu and Kashmir is a very unique state due to its ecological and environmental diversity that prevails in three regions of the state which are Jammu, Kashmir and Ladakh. Trout is a very high value cold water species mainly originated from North America (Waweru, 2012) and in Jammu and Kashmir we have two species namely Rainbow and Brown trout ( Hassan and Pandey, 2012). Trout cultured is mainly carried out in the Kashmir region of the state due to its favourable climatic conditions (Gawa et al., 2016; Gawa et al., 2017). Other than Jammu and Kashmir trout is also found in the states of Himachal Pradesh, Nilgiris of Tamil Naidu, Uttrakhand, Sikkim and Arunachal Pradesh (Ayyappan et al., 2006) . The state of Jammu and Kashmir plays pioneering role in trout culture followed by Himachal Pradesh. The Directorate of Cold Water Fisheries Research (Bhimtal) is premiere research institute working on trout culture and to propagate the culture of this high value fish in the Trans-Himalayan region (DCFRI, 2013-14). Since trout culture is an intensive culture system and is totally dependent on artificial feed; it is very important to have a continuous supply of cheap feed for smooth running of the culture system. In both the states of Jammu and Kashmir and Himachal Pradesh trout hatcheries and feed mills has been established with the financial and technical assistance from European Economic Community in mid80 's which are still in operational condition (Ayyappan et al., 2006). The state has two feed mills located at the Kokarnag trout Fish farm in Anantnag district and other at Manasbal National Fish Seed Farm in Ganderbal District (Gawa et al., 2016). The Kokarnag Trout Fish farm is largest Trout fish farm in India and it is probably the largest of its kind in Asia too. The first feed mill was installed at this Kokarnag Trout Farm with the financial and technical assistance from European Economic Commission (EEC) which was brought from Holland in the year 1984. This feed mill is still in good functional condition and it was reported to have the production capacity of 5 to 6 quintals per day and 
based on the requirement of the feed this feed mill is operated at the farm. When the state fisheries department started privatizing trout culture in the year 200910 under RKVY Scheme ( DoF, 2016) there was an increase in the demand for trout feed in the state. So in order to meet the growing demand for trout feed due to growing number private trout farmers in the state, the fisheries department successfully established a new feed mill at Manasbal National Fish Seed Farm with the financial assistance from NFDB in the year 2012 which was also from brought from Netherland. This feed mill was fully computerized and reported to have a production capacity of 1 ton per hour. With this development the requirement of feed in the state has been satisfied and now almost all the feed required in the state is fulfilled from this newly established feed mill. This development can be viewed as a boost in trout culture in the state and with continuous supply of feed in the state, there is a rise in the number of young entrepreneurs taking up trout culture as source of livelihood looking at the success of other existing trout farmers. Understanding the fact that feed is the most critical inputs in trout culture as trout are cultured in continuous flowing rich oxygenated cold water which are devoid of primary productivity and its total dependency on the artificial feed there is need to study economics of trout feed production. And since profitability of trout farming heavily depends on the price and quality of feed used in its culture, hence this study has been carried out to get insight of trout feed production in the state. The economic analysis of trout feed production will provide some input for improving the trout value chain.

\section{MATERIALS AND METHODS}

Methodology: Trout culture is an intensive culture system which is solely dependent on the artificial feed for its successful operation. So, feed is single most important factor in an intensive culture system which has great influence on deciding the profitability of the system. Therefore to understand the economics of trout feed production system in the state of Jammu and Kashmir the present study was carried out with the objective to estimate the economics and the factors influencing in it. At present the state has two trout feed mills one located at Kokarnag trout fish farm in Anantnag district and the other at Manasbal National Fish Seed Farm in Ganderbal district. The data was collected from both the trout feed mills and since scale of operation was not same, hence economics has been worked out separately to have comparative study between the two feed mills. About 60 trout farmers were interviewed 30 each from Anantnag and Ganderbal district respectively. The primary data was collected with help of pre-tested open type questionnaire through personal interview and the secondary data was collected from literature, state fisheries department, fisheries department official website and other secondary sources available.

To determine the cost and return in trout feed production following variable and tools has been followed.

Fixed cost: A cost that doesn't change with an increase or decrease in the level of production. Fixed costs are the expenses that have to be paid by a farm, independent of any business activity. It is one of the two components of the total cost, along with variable cost. Fixed cost includes following items:

Depreciation on fixed assets: calculated @10\% using straight line method.

Interest on fixed capital: It was calculated @ $12 \%$ per annum on fixed capital.

Expenses on repair and maintenance of fixed assets: estimated based on the information collected from each feed mills separately.

Salary of permanent human labour.

Variable cost: Variable cost is that part of the total cost which changes with change in output level. The daily expenses incurred are termed as operating cost or variable cost. It includes the following items:

Raw material

Fuel

Electricity cost

Hired human labour cost

Transportation cost

Miscellaneous cost

Interest on working capital (It has been calculated at $8.75 \%$ interest rate for a period of 6 months) followed by Gawa et al. (2017).

Gross income: It was worked out by multiplying the quantity of produce with respective prices.

Gross income $=Q^{*} P$

Where,

$\mathrm{Q}=$ quantity of trout produced $(\mathrm{kg})$

$\mathrm{P}=$ Selling price of trout $(\mathrm{Rs} . / \mathrm{kg})$

Net income: The return left after deducting all the expenditure such as fixed cost and variable cost from gross income.

Net income $=G I-T C$

Where,

$\mathrm{GI}=$ Gross income

$\mathrm{TC}=$ Total cost

$T C=T F C+T V C$

Where,

TFC $=$ Total fixed cost

TVC $=$ Total variable cost

Benefit cost ratio (B:C Ratio): B: C ratio was used to ascertain the viability of the business. It estimates the ratio of benefit and cost incurred in the business. Mathematically, it can be expressed as

$B: C$ Ratio $=$ Gross income $/$ Total cost

Feed conversion ratio: The feed conversion ratio of trout feed was estimated using formula fallowed by 
Logan and Johnston (1992).

FCR $=$ Food fed / Weight gain .

\section{RESULTS AND DISCUSSION}

Feed ingredient, their source and unit cost: The feed ingredient used in Jammu and Kashmir for trout was of both plant and animal origin which is presented in the Table. $1 \& 2$ along with their source and unit cost below. The trout feed mills produce different sizes of extruded pellets of variable sizes for different life stages of trout. The ingredient for formulating the feed was procured from different parts of the country like Mangalore and Mumbai since these ingredients were not locally available. The ingredients like fish meal and soya bean were procured from Mangalore at Rs.99 and Rs.58.7 per $\mathrm{kg}$ respectively. Likewise other ingredient like mineral mix, Vitamin B complex and Vitamin AB2DK3 are procured form Mumbai at Rs.35, Rs.211 and Rs.399 per kg respectively. Other ingredients like wheat, oil, sodium alginate, Vitamin $\mathrm{C}$ and vitamin $\mathrm{E}$ are locally available at Rs.25.75, Rs.119.3, Rs.281, Rs.817 and Rs.988 per kg respectively. It can be seen that the necessary nutrient required in the formulation of trout feed are being followed but there is need to make the ingredient to be made available within the state, since some of the ingredient are availed from far flung places like Mumbai and Mangalore which results in high transportation cost. So, in order to reduce the cost of production there is need to look for locally

Table 1. Different types of feed manufactured in Kashmir.

\begin{tabular}{ll}
\hline Pellet Type & Abbreviation \\
\hline Starter Diet(crumble) & -- \\
Pellet 1 & P1 \\
Pellet 2 & P2 \\
Pellet 3 & P3 \\
Pellet 4 & P4 \\
Pellet 5 & P5 \\
\hline
\end{tabular}

Table 2. Feed ingredient, their source and unit cost.

\begin{tabular}{lcc}
\hline Feed Ingredient & Source & unit cost (Rs/kg) \\
\hline Fish meal & Mangalore & 99 \\
Wheat & Local & 25.75 \\
Soya bean & Mangalore & 58.7 \\
Oil & Local & 119.3 \\
sodium alginate & Local & 281 \\
mineral mix & Mumbai & 35 \\
Vitamin B complex & Mumbai & 211 \\
Vitamin AB2DK3 & Mumbai & 399 \\
Vitamin C & Local & 817 \\
Vitamin E & Local & 988 \\
\hline
\end{tabular}

available ingredients and Tudor et al (1996) showed there is no significant change in FCR by replacing animal protein source with plant protein source which are locally available. Nevertheless the feed was of high quality and the state fisheries department claims it FCR of less than 2.

Different types of pellets feed for different sizes of fish: The trout is active feeder and it has different life stages with different nutritional requirement like any other living organism. Table 3 presents the different types of feed used at different life stages which is followed in Jammu and Kashmir. It has been prepared by discussion with the farm mangers running who were in -charge of the feed mills and were having long practical experience in trout farming.

The price for different types of pelleted feed was same and was fixed by the department of fisheries during the study which was Rs.73/kg. Like any other fish trout actively starts feeding on external feed that is at early fry stage when its yolk sack is exhausted and has size less than $5 \mathrm{~g}$. It is then they provide early fry with starter diet also known as crumbles which is like fine powder of crush pelleted feed of sizes less than 0.5 $\mathrm{mm}$ to suite is mouth size and the feeding frequency is 6 times a day as it is recommended to feed 2 to 3 percent of body weight. Between $5 \mathrm{~g}$ to $25 \mathrm{~g}$ which is called the fry stage starter diet is replaced by $\mathrm{P} 1$ which is of size 0.5 to 1 and the feeding frequency is reduced to 3 times a day. When fry reaches to fingerling of size $26 \mathrm{~g}$ to $50 \mathrm{~g}$ the feeding frequency is reduced to 2 times a day i.e one in the early morning and one in the early evening with $\mathrm{P} 2$ which is size 1 to $2 \mathrm{~mm}$ which is continued in other stages of life cycle. Other sizes of pellet are P3 (2-4mm), P4 (4-5mm) and P5 (5) for yearling (51-100g), table fish (101-150g) and brooder (>250g) sizes respectively. Similar study has been done by Hinshaw (1990) in which after starter diet he used granule and then pellet for different sizes of feed for different sizes of trout fish. It can be seen that trout feed mill produced different sizes of feed to suit the different feeding capacity of fish based on its size, which in turn result in better feed utilization and reduced wastage of feed.

Feed Conversion Ratio: The feed conversion ratio has been estimated from the data gather on feed utilization on the sampled farms and presented in the table 4.

The average production on the sample trout farms was $1105.67 \mathrm{~kg}$ and the average number of seed used was

Table 3. Different Types of pellets feed for different sizes of fish.

\begin{tabular}{lccccc}
\hline Pellet Type & stage & Size of fish (g) & Size of pellet (mm) & frequency/day & Price/Kg \\
\hline Starter Diet (crumble) & Early fry & $<5$ & $<0.5$ & 6 & 73 \\
P1 & Fry & $5-25$ & $0.5-1$ & 3 & 73 \\
P2 & Fingerling & $26-50$ & $1-2$ & 2 & 73 \\
P3 & Yearling & $51-100$ & $2.0-4$ & 2 & 73 \\
P4 & Table size & $101-150$ & $4-5$ & 2 & 73 \\
P5 & Brooder & $>250$ & 5 & 2 & 73 \\
\hline
\end{tabular}


Table 4. Feed conversions Ratio Sample: 60

\begin{tabular}{ll}
\hline Particulars & values \\
\hline Average Production(Kg) & 1105.67 \\
Average seed Used(nos) & 6910.74 \\
Averaged Total weight of seed used(@5g/piece) & 34553.7 \\
Average weight Gain on Farm(kg) & 1071.12 \\
Average feed Used(kg) & 1462.84 \\
FCR & 1.56 \\
\hline
\end{tabular}

6910.74. The total weight of seed excluding the weight attained at hatchery was found out to be $932.9 \mathrm{~kg}$ assuming $25 \mathrm{~g}$ as average weight of fry. The average feed used at the farm was estimated around $1462.84 \mathrm{~kg}$. Using these values the FCR by weight method was found out to be 1.56 which was found to be less than department estimate which was 2. Bureau et al., (2003) also reported FCR in the range of 1.14 to 1.29 for rainbow trout in Ontario (Canada) in cage culture. Dunning and Sloan (2001) in North Carolina (USA) also reported FCR of 1.1 for in fingerling and 1.3 for adults fish. These study shows that trout has a higher feed conversion efficiency and the present study also found in line with these studies with similar results, hence it support department of fisheries claims of FCR less than 2.

Fixed capital investment in fish feed mill: The investment incurred in the establishment of sample trout feed mill was estimated separately for the two feed mills along with their average and presented in the table 5 .

The study showed that trout feed mill requires high initial capital investment. The investigation of total fixed investment in the feed mills found to be varying from Rs.1.92 crore for Kokarnag to 12.06 crore for Manasbal trout feed mill with average of about Rs.7 crore per feed mill. Purchase of feed mills absorbed the major share of investment which accounted an average of about 71.44 percent of total fixed capital investment that varied from 54.06 percent for Kokarnag to 74.61 percent for Manasbal trout feed mill respectively. Other investments incurred in the trout feed mill were feed mill shed and feed store having a share of 11.79

Table 5. Fixed capital investment in trout feed mill.

\begin{tabular}{|c|c|c|c|c|}
\hline \multirow{2}{*}{ Particular } & \multicolumn{4}{|c|}{ Investment in trout feed mill (Rs./feed mill) } \\
\hline & Kokarnag & Manasbal & Overall & \%age Share \\
\hline Feed mill office & 1500000 & 100000 & 800000 & 1.14 \\
\hline Feed Mill & 10000000 & 90000000 & 50000000 & 71.44 \\
\hline Feed Mill Shed & 1500000 & 15000000 & 8250000 & 11.79 \\
\hline Feed store & 3000000 & 7500000 & 5250000 & 7.50 \\
\hline Generator Set & 1000000 & 1600000 & 1300000 & 1.86 \\
\hline Generator Shed & 300000 & 500000 & 400000 & 0.57 \\
\hline Power connection and lighting & 500000 & 4900000 & 2772500 & 3.96 \\
\hline Transport vehicle & 1400000 & 1000000 & 1200000 & 1.71 \\
\hline Office inventory & 8000 & 20000 & 14000 & 0.02 \\
\hline Total & 19208000 & 120620000 & 69986500 & 100 \\
\hline
\end{tabular}

Table 6. Cost and return in trout feed production.

\begin{tabular}{|c|c|c|c|c|}
\hline \multirow[t]{2}{*}{ Particulars } & \multicolumn{4}{|c|}{$\begin{array}{l}\text { Cost and return in trout feed production } \\
\text { (Rs./feed mill/annum) }\end{array}$} \\
\hline & Kokarnag & Manasbal & Overall & \%age Share \\
\hline \multicolumn{5}{|l|}{ A. variable cost } \\
\hline Raw material & 19202350 & 30292200 & 24747275 & 56.37 \\
\hline Fuel & 1300 & 4160 & 2730 & 0.01 \\
\hline Electricity & 16032 & 16032 & 16032 & 0.04 \\
\hline Transportation & 45455 & 66980 & 56218 & 0.13 \\
\hline Hired Human labour & 30000 & 45000 & 37500 & 0.09 \\
\hline Packaging & 7500 & 15000 & 11250 & 0.03 \\
\hline Miscellaneous & 10000 & 10000 & 10000 & 0.02 \\
\hline Total variable cost & 19312637 & 30449372 & 24881005 & 59.16 \\
\hline \multicolumn{5}{|l|}{ B. Fixed cost } \\
\hline Depreciation of fixed assets & 3065160 & 9244200 & 6154680 & 13.97 \\
\hline Interest on fixed capital & 2322960 & 14497800 & 8410380 & 19.08 \\
\hline Annual repair and Maintenance & 1015000 & 1112500 & 1063750 & 2.41 \\
\hline Salaries of permanent staff & 1740000 & 3000000 & 2370000 & 5.38 \\
\hline Total fixed cost & 8143120 & 27854500 & 17998810 & 40.84 \\
\hline Total cost $(\mathrm{A}+\mathrm{B})$ & 27455757 & 58303872 & 42879815 & 100 \\
\hline Total production(kg) & 350000 & 646300 & 498150 & \\
\hline Sell price (Rs/kg) & 73 & 73 & 73 & \\
\hline Gross revenue & 25550000 & 47179900 & 36364950 & \\
\hline Return over variable cost & 6237363 & 16730528 & 11483946 & \\
\hline Cost of production (Rs/kg) & 78.45 & 90.21 & 84.33 & \\
\hline
\end{tabular}


Table 7. Constraints faced by feed supplier.

\begin{tabular}{llcc}
\hline S.N. & Problem & $\begin{array}{c}\text { Rank Given By Kokarnag trout } \\
\text { Mill (K) }\end{array}$ & $\begin{array}{c}\text { Rank Given by Manasbal trout } \\
\text { feed mill (M) }\end{array}$ \\
\hline 1 & Availability of raw material & I & I \\
2 & High price of raw material & II & II \\
3 & Low demand for feed & III & III \\
4 & Lack of marketing facility & IV & IV \\
5 & High cost of procurement & V & V \\
6 & Storage facility & VI & VI \\
7 & Production units management & VII & VI \\
8 & Shelf life of feed & X & X \\
9 & Poor road and transportation & IX & VIII \\
10 & Lack of skill labour & & Cos \\
\hline
\end{tabular}

and 7.50 percent share in total fixed investment, respectively. Hence it concludes that feed mill along with feed mill shed are the major investment in trout feed mill that absorbed about 83 percent of the total fixed investment. So, the study suggest that it is very important to decide the capacity of feed mill according to demand because cost increase with increase in size of the feed mill. The newly installed feed mill at Manasbal has a capacity of 1 ton per hours, while the Kokarnag trout feed mill produce $600 \mathrm{~kg}$ to 1 ton feed per day as reported by the respective farm managers.

Cost and return in trout feed production: Feed, the costliest input in trout farming carried out in concrete structure like raceway and play a major role in deciding its profit margin. The return on investment was examined for feed manufacturers in Kashmir and presented in the table 6 .

Total cost of production per feed mill per annum ranged from Rs.2.75 crore in case of Kokarnag to Rs.5.83 crore in Manasbal feed mill, generating a gross return of 2.56 crore and 4.72 crore, respectively at a price of Rs.73/kg fixed by state fisheries department during the study period. The variable cost and fixed cost occupied about 59.16 and 40.84 percent of the total cost. Purchase of raw material for feed preparation accounts for more than 50 percent of the total cost. This was due to reason that most of the feed ingredients were imported into the state from the coastal states like Karnataka and Maharashtra at very high cost. Other costs incurred in feed manufacturing was interest on fixed capital, depreciation of fixed capital, salaries and annual repair and maintenance with share of $19.08,13.97,5.38$ and 2.41 percent, respectively in total cost. The average cost of production of trout feed was Rs.84.33 per kg which ranged from Rs.78.45 per $\mathrm{kg}$ in Kokarnag trout feed mill to Rs.90.21 per $\mathrm{kg}$ in Manasbal trout feed mill. The average return over variable cost was Rs.1.15 crore per feed mill per annum which can be considered very sound profit for a firm in public sector. Since most of the fixed cost was met from subsidy and assistance from ECC (European Economic Community) and NFDB (National Fisheries Development Board) and the both feed mills are under state fisheries department, hence return over variable cost remain important for feasibility of trout feed production. Tudor et al (1996) in an experiment conducted in Illinois State University showed that cost can be significantly reduced by replacing animal protein source with plant protein sources which are locally available. In this they replaced fish meal with locally available grains and grains by product saw a significant economics difference between purchasing and feeding a commercial prepared feed and onsite processing and feeding. Similar study also required trout feed production in Kashmir where they also used fish meal as main protein source. This will help in cost reduction and profit maximization in trout farming in the valley.

Constraints faced by feed suppliers: As discussed earlier that in Kashmir there are only two trout feed mills one at Kokarnag and another at Manasbal. The constraints faced by both the feed mills were identified and were ask to rank according to the severity perceived by respective feed mills. Since Rank Based Quotient (RBQ) technique or any other statistical tool was not justifiable so, the responses were listed and presented in the tabular form in table 7.

The results obtained from two feed mills were compared and it was found that both the feed mill rank availability of raw material for trout feed production as rank I. The trout feed need high amount of protein, vitamin and micronutrients and these raw material are not available in the state. They have to import these items from coastal state like Karnataka and Maharashtra leading to high transportation. The required fish meal was also found to be imported from Mangalore and where vitamins and micronutrients was imported from Mumbai. The high price of raw material has been rank second by both the feed mills. The raw materials are costly since it has to be imported from other state. Thorarinsdottir et al. (2011) in a project in Nordic countries concludes that feed raw material, their origin, quality, feed manufacturing process and transportation cost are main concern in aquaculture industry which is found to be inlined with the present study. Third most constraint was low demand for feed in the valley. Fourth constraint was found to be marketing facility, there is no marketing infrastructure was the 
sale of the trout feed in the Kashmir valley. Fifth most constraints which is found by both the feed mills was high cost of procurement. High cost of procurement was found to incur in transportation of the feed ingredient. Constraints were found to get different ranking from the two feed mills, low demand $(\mathrm{K}=\mathrm{V}, \mathrm{M}=\mathrm{VI})$, production units management $(\mathrm{K}=\mathrm{VII}, \mathrm{M}=\mathrm{IX})$ storage facility $(\mathrm{K}=\mathrm{VI}, \mathrm{M}=\mathrm{VII})$, lack of skill labour $(\mathrm{K}=\mathrm{IX}$, $\mathrm{M}=\mathrm{VIII})$ respectively. Both the feed mills found poor road and transportation last constraints. It was found that top fours constraints were found to be same and while having difference of opinion for the other constraints. Since raw material is most important in trout feed production and all the top constraints are directly or indirectly related with raw material except marketing of trout feed, there is strong need to find substitutes for raw material which are locally available which will help in cost minimisation.

\section{Conclusion}

The study found that trout feed production in Jammu and Kashmir follows standard methods using all the required ingredients for producing different sizes of feed for different sizes of fish. The produced feed was found out to be of high quality with FCR of 1.56. The fixed investment investigation showed that trout feed mill requires high initial capital investment with average investment of about Rs.7 crore per feed mill. In the cost and return analysis revealed that variable cost and fixed cost occupy about 59.16 and 40.84 percent to the total cost respectively. It can be concluded that in near future the percentage of fix investment will reduce due declining nature of fixed cost in long run. The average cost of feed production was found to be Rs.84.33/kg but the government was selling the feed at Rs.73/kg since its main motive is development. Even though the cost of production was it is important to see that the feed mills were nearly able to meet their variable cost even though it is under public sector, this gives a good indication that in long run it will lead to economic feasibility. Since at present it can be concluded that feed mill are running at suboptimal level due low demand but this scenario is not going to be same as more and more private trout farm are coming up in the state and other state like Himachal, Sikkim and Arunachal in neighbouring state and they can also market the extra produce to these states where trout culture is catching up. The study also found strong need to find alternative raw material that can be made available with the state which will results in cost minimisation and profit maximisation.

\section{REFERENCES}

Ayyappan, S., Jena, J.K., Gopalakrishnan, A. and Pandey, A.K (2006). Handbook of fisheries and aquaculture. Indian Council of Agricultural Research. New Delhi 100012

Bureau, D.P., Gunther, S.J. and Cho, C.Y. (2003). Chemical composition and preliminary theoretical estimates of waste outputs of rainbow trout reared in commercial cage culture operations in Ontario. North American Journal of Aquaculture, 65(1):33-38.

DoF (Department of Fisheries) (2016). Official website of Department of Fisheries, Jammu and Kashmir. RKVY Scheme. Accessed on 24 October 2016.

Dunning, R. and Sloan, D., (2001). Aquaculture in north Carolina: Rainbow trout-inputs, outputs and economics. Raleigh, NC: North Carolina Department of Agriculture and Consumer Services.16pp

Gawa, S., Kumar, N.R., Mahida, N. and Hatte, V. M. (2017). Livelihood Option through trout seed production in Jammu and Kashmir: An economic analysis. Fishery Technology $54: 209$ - 214

Gawa, S., Kumar, N.R., Tiwari, V.K., Prakash, S., Yadav, V.K and Wani, G.B (2017). Trout culture in KashmirAn opportunity for profitable enterprise. In: Social entrepreneurship in Aquaculture. (Ed. Sinha, V.R.P., Krishna, G., Keshavanth, P and Kumar, N.R). Narendra Publishing House, Delhi, India. 381-389pp

Gawa, S., Kumar, N.R., Wani, G.B., Hatte, V.M. and Vinay, A., (2016). Mapping the core processes and identifying actors along with their roles, functions and linkages in trout value chain in Kashmir, India. World Academy of Science, Engineering and Technology, International Journal of Biological, Biomolecular, Agricultural, Food and Biotechnological Engineering, 10(6):317-321

Hassan, N.U. and Pandey, D.N., 2012. Present status of trout fisheries in Jammu and Kashmir. IOSR Journal of Pharmacy, 2(5):35-37.

Hinshaw, J.M., 1990. Trout production: feeds and feeding methods. SRAC Publication (USA).

ICAR-Directorate of Coldwater Fisheries Research (2014), Annual Report , 2013-14

Logan, S.H. and Johnston, W.E., 1992. Economics of commercial trout production. Aquaculture, 100(1):25-46.

Thorarinsdottir, R.I., Jokumsen, A., Bjornsson, B.T and Torrissen, $\mathrm{O}$ (2011). Local raw material for production of fish feed for aquaculture, nordic innovation centre, Project No: 10102. pp.64

Tudor, K. W., Rosati, R. R., O'Rourke, P. D., Wu, Y. V., Sessa, D. and Brown, P. (1996). Technical and economical feasibility of on-farm fish feed production using fishmeal analogs. Aquacultural Engineering, 15(1):53-65

Waweru, P.T. (2012). Trout fish value chain analysis, Jitunze Environment Self Help Group, pp.33 